\title{
PENGARUH CITRA MEREK DAN PROMOSI TERHADAP LOYALITAS KONSUMEN DENGAN KEPUASAN SEBAGAI VARIABEL INTERVENING PADA PRODUK KANTONG PLASTIK TOMAT
}

\author{
Sugiyanto $^{1^{*}}$, Robert Aprioman ${ }^{2}$ \\ ${ }^{1,2}$ Universitas Esa Unggul \\ Email: sugiyanto@esaunggul.ac.id
}

\begin{abstract}
Abstrak
Tujuan penelitian ini adalah untuk menganalisis pengaruh citra merek dan promosi terhadap loyalitas konsumen dengan kepuasan sebagai variabel intervening pada produk kantong plastik tomat. Jenis penelitian ini menggunakan jenis penelitian asosiatif. Sumber data yang digunakan yaitu sumber data primer. Dalam penelitian ini variabel dependen adalah loyalitas (Y), variabel independen adalah citra merek (X1) dan promosi (X2), serta variabel intervening adalah kepuasan konsumen (Z). Uji data dalam penelitian ini terdiri dari uji validitas, uji reliabilitas dan uji analisis jalur. Berdasarkan analisis data hasil penelitian, dapat disimpulkan bahwa: 1) Citra Merek (X1) dan Promosi (X2) berpengaruh terhadap kepuasan (Z); 2) Citra Merek (X1) dan Promosi (X2) berpengaruh terhadap Loyalitas (Y); 3) Kepuasan (Z) berpengaruh terhadap Loyalitas (Y); dan 4) Citra Merek ( $\mathrm{X}_{1}$ ) dan Promosi (X2) memiliki pengaruh terhadap loyalitas konsumen melalui kepuasan konsumen Produk Kantong Plastik merek Tomat.
\end{abstract}

Kata Kunci: Pengaruh, Citra Merek, Promosi, Loyalitas Konsumen, Kepuasan.

\begin{abstract}
The purpose of this study was to analyze the effect of brand image and promotion on consumer loyalty with satisfaction as an intervening variable on tomato plastic bag products. This type of research uses associative research. The data source used is the primary data source. In this study the dependent variable is loyalty $(Y)$, the independent variable is brand image (XI) and promotion (X2), and the intervening variable is consumer satisfaction (Z). The data test in this study consisted of a validity test, a reliability test and a path analysis test. Based on the analysis of the research data, it can be concluded that: 1) Brand Image (X1) and Promotion (X2) affect satisfaction (Z); 2) Brand Image (X1) and Promotion (X2) affect Loyalty (Y); 3) Satisfaction $(Z)$ has an effect on Loyalty (Y); and 4) Brand Image (X1) and Promotion (X2) have an influence on consumer loyalty through consumer satisfaction of Tomato brand Plastic Bag Products.
\end{abstract}

Keywords: Influence, Brand Image, Promotion, Consumer Loyalty, Satisfaction.

\section{A. PENDAHULUAN}

Kantong Plastik merupakan satu dari sebagian besar benda yang tidak bisa dipisahkan dari kehidupan sehari-hari masyarakat. Pada saat ini, perkembangan produk plastik cukup pesat. Dengan meningkatnya tingkat kebutuhan masyarakat, maka kebutuhan masyarakat juga semakin berkembang. Hal ini pun mendorong masyarakat untuk lebih selektif dalam memilih produk yang mereka anggap paling sesuai dan benar-benar dapat menunjang kegiatan dan keinginan mereka. Industri kantong kemasan plastik sampai saat ini masih dilirik dan tidak sedikit produsen berlomba-lomba untuk menciptakan produk jadi kantong kemasan plastik jenis baru. 
Di Indonesia fungsi dari kantong plastik selain untuk packing digunakan juga sebagai wadah, dan kantong kemasan belanja untuk membawa berbagai macam barang belanjaan, seperti sayur-sayuran, buah-buahan, makanan, minuman, sampai alat rumah tangga lainnya. Penggunaan kantong plastik di Indonesia masih sangat tinggi karena kegunaannya selain dapat mempercantik dan memberikan daya tarik tersendiri pada produk ataupun makanan yang dibungkusnya, kantong plastik dianggap praktis dan murah. Hal tersebut dapat dilihat dibawah ini alasan masyarakat menggunakan kantong kemasan plastik.

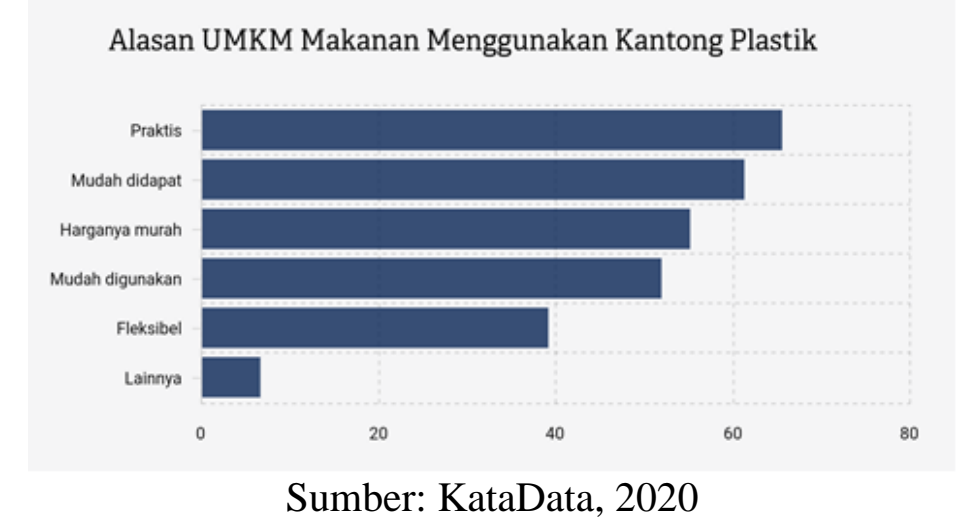

Gambar 1. Alasan UMKM Menggunakan Kantong Plastik

Dari data diatas, dapat diketahui penggunaan produk kantong kemasan sudah menjadi kebiasaan masyarakat bahkan sejak puluhan tahun silam. Dalam sejarahnya kantong kemasan berbahan dasar plastik pertama diciptakan untuk menyelamatkan bumi dari penggunaan kantong kertas, karena kantong kertas dahulu dianggap berpotensi menimbulkan pemotongan pohon secara besar-besaran apabila semakin banyak manusia menggunakan kantong kemasan berbahan dasar kertas. Dengan adanya kantong kemasan plastik, masyarakat dimudahkan dalam hal kegiatannya. Banyak kegiatan atau bisnis yang harus dilakukan dengan menggunakan kantong plastik untuk mempermudah kegiatan usahanya. Hal ini mendorong distributor produk jadi kantong kemasan berusaha masuk dengan membawa berbagai mereknya. Banyak distributor kantong kemasan plastik yang sudah malang melintang dan mengusai pasar tradisional di Indonesia, sebut saja merek Tomat, Apollo, Bawang, dan Dynaplast.

Tomat adalah salah satu merek terkenal yang sudah lama berkiprah di pasar produk jadi kantong kemasan plastik dan menjadi pioneer saat ini, Kantong kemasan merek Tomat didistribusikan oleh PT. Panca Budi Niaga, perusahaan yang sedang terus berkembang pesat dan merupakan salah satu perusahaan pertama di Indonesia yang beriklan di TV. Sepanjang tahun 2020, merek Tomat tercatat (TBI) memiliki market share sebesar 40.4\%. Urutan kedua ditempati merek Apollo dengan angka market share 11.8\%, dan merek bawang diurutan ketiga dengan angka market share 10.8\%. Terlihat Apollo sudah dipepet oleh Bawang diurutan ketiga hanya berselisih tipis dengan Bawang, yakni 1.0\%.

Tomat masih menjadi produk Top Brand teratas selama dua tahun berturut-turut, Munculnya merek-merek lain PT. Panca Budi Niaga perlahan harus kehilangan pelanggannya, perubahan tersebut dikarenakan perilaku beli konsumen yang sangat tergantung dari jumlah uang atau biaya yang dikeluarkan untuk mendapatkan barang atau jasa. Seperti perilaku konsumen membeli produk kantong plastik, berbeda sekali ketika seseorang akan membeli sebuah kendaraan. Tentu proses untuk mendapatkannya akan lebih rumit dibandingkan proses 
pembelian produk kantong plastik. Setidaknya ada informasi yang detail bagaimana tentang pembiayaannya, dan bagaimana after sales. Jadi, perubahan proses perilaku konsumen diakibatkan adanya perbedaan sebuah risiko.

Berbicara mengenai loyalitas konsumen PT. Panca budi Niaga, masih dibutuhkan usaha yang lebih dan continue untuk meningkatkannya. Apabila dilihat dari TBI di tahun 2019, merek Tomat berada diteratas dengan angka 46.3\%, dan merek Apollo satu tingkat dibawahnya yaitu 15.6\%. Akan tetapi $46.3 \%$ dan $15.6 \%$ dari pengguna Tomat dan Apollo, kemungkinan masingmasing menggunakan merek lain seperti Dyna Plast, Bawang dan lain-lain. Apabila dilihat dari besaran market share Tomat telah mengalami penurunan. Data TBI (Top Brand Index) menunjukan bahwa tahun 2019, Tomat mengusai pasar dengan angka 46.3\%, sedangkan di tahun 2020, market share Tomat hanya sebesar 40.4\%, atau terserap sekitar lebih kurang 5.9\% dari 2019 sampai 2020. Hal ini menunjukan bahwa konsumen Tomat belum memiliki loyalitas yang tinggi karena masih menggunakan produk merek lain yang serupa dan diduga beralih ke produk lain seperti merek Bawang. Dikatakan demikian karena pada tahun 2019 tercatat Bawang berada di posisi keempat terlampau tiga tingkat dari Tomat dengan perolehan angka 7.9\%. Sedangkan tahun 2020 Bawang memperoleh angka $10.8 \%$ naik satu tingkat dari posisi keempat menjadi posisi ketiga, dengan data pertumbuhan $2.9 \%$, dimana kondisi saat itu Tomat, Apollo, Dyna Plast dan Bangkuang mengalami penurunan.

Dalam loyalitas konsumen perlu adanya suatu promosi agar dapat menarik konsumen dalam membeli produk tersebut. Promosi merupakan salah satu variabel pemasaran yang digunakan oleh konsumen sebagai acuan dalam memilih barang atau jasa yang diinginkan. Keterkaitan promosi dan keputusan pembelian adalah suatu cara memperkenalkan, mengkomunikasikan manfaat dari sebuah produk atau jasa dan mengajak konsumen untuk menggunakan produk yang ditawarkan.

Faktor lain yang juga berperan yakni citra merek atau brand image. Citra merek atau brand image merupakan representasi dari keseluruhan persepsi terhadap merek dan dibentuk dari informasi dan pengalaman masa lalu terhadap merek itu. Konsumen yang memiliki citra yang positif terhadap suatu merek, akan lebih memungkinkan untuk melakukan pembelian. Terdapat banyak faktor yang menyebabkan konsumen memilih produk kantong plastik lain sebagai pilihannya, diantaranya karena merek yang terkenal, dan promosi produk yang membuat konsumen dapat mengenal lebih dekat produk yang ditawarkan, sampai dengan beberapa faktor lainnya. Untuk dapat mengantisipasi pesatnya persaingan yang dihadapi, PT. Panca Budi Niaga Tangerang tetap mempertahankan eksistensinya, maka perlu diadakan penelitian sejauh mana faktor-faktor perilaku konsumen terhadap loyalitas produk kantong plastik tersebut.

Berdasarkan pra survei yang dilakukan oleh penulis terhadap 30 responden di wilayah Tangerang Kota memperlihatkan bahwa $60 \%$ responden menjawab keamanan produk bagi makanan dan minuman adalah hal utama yang dipertimbangkan dalam melakukan pembelian Kantong Plastik, karena akan mempengaruhi usahanya. Sedangkan 13\% responden diantaranya tidak mengetahui merek Kantong Plastik responden membeli berdasarkan kebutuhan dan tidak berdasarkan merek. Sebanyak $17 \%$ responden mengatakan bahwa kantong plastik yang digunakan selalu merek Tomat karena merasa puas dan rasa trauma dengan kualitas buruk yang pernah dialami pada merek lain. Sementara itu, sebanyak $10 \%$ pelanggan mengatakan merek kantong plastik yang digunakan tidak hanya merek Tomat, tergantung 
ketersediaan stok toko dan selama kantong kemasan yang diberikan sesuai dengan kebutuhan tidak menjadi masalah. Hasil ini memperlihatkan tidak banyak pelanggan yang fanatik dengan merek produk Kantong Plastik ketika akan melakukan pembelian.

Hal ini mengidentifikasi terciptanya perasaan tidak puas dan terjadinya penurunan tingkat loyalitas, sehingga dalam penelitian ini variabel dependen Loyalitas Konsumen (Y), Kepuasan (Z), dan variabel independennya (X). Berdasarkan pada penelitian terdahulu, mengindikasi Research Gap dari variabel independen yang mempengaruhi Loyalitas Konsumen yaitu penelitian yang dilakukan oleh Ananda (2018) bahwa citra merek berpengaruh positif terhadap loyalitas konsumen. Namun hal ini bertentangan dengan penelitian yang dilakukan David (2018) yang menunjukan bahwa citra merek berpengaruh langsung terhadap loyalitas konsumen. Menurut penelitian yang dilakukan oleh Wibawa \& Farida (2018) bahwa promosi berpengaruh positif terhadap loyalitas konsumen. Hal ini bertentangan dengan penelitian yang dilakukan Muhammad (2018) yang menunjukan bahwa promosi berpengaruh terhadap loyalitas konsumen.

\section{B. LITERATURE REVIEW}

\section{Citra Merek}

Menurut Kotler \& Armstrong (2008) merek adalah pengaruh deferensiasi positif bahwa jika pelanggan mengenal nama merek, pelanggan dalam merespon produk atau jasa. Menurut Tjiptono (2011) brand image adalah deskripsi tentang asosiasi dan keyakinan konsumen terhadap suatu merek.

Menurut Shimp \& Craig (2013) dalam Sangadji \& Sopiah (2013), citra merek (brand image) dapat dianggap sebagai jenis asosiasi yang muncul dibenak konsumen ketika mengingat sebuah merek tertentu. Asosiasi tersebut secara sederhana dapat muncul dalam bentuk pemikiran atau citra yang dikaitkan dengan suatu merek, sama halnya ketika kita berpikir mengenai orang lain. Indikator Citra Merek menurut Bilson (2011) ada tiga, yaitu: a) Citra Pembuat (Corporate Image) yaitu sekumpulan asosiasi yang dipersepsikan konsumen terhadap perusahaan yang membuat suatu barang atau jasa; b) Citra Pemakain (User Image) yaitu sekumpulan asosiasi yang dipersepsikan konsumen terhadap pemakai yang menggunakan suatu barang atau jasa; dan c) Citra Produk (Product Image) yaitu sekumpulan asosiasi yang dipersepsikan konsumen terhadap suatu barang atau jasa.

\section{Promosi}

Promosi merupakan salah satu kegiatan pemasaran yang dilakukan oleh tenaga pemasar guna memberikan informasi sebuah produk dan mendorong konsumen untuk melakukan pembelian pada produk yang ditawarkan. Masyarakat umum biasanya dapat melihat bentuk promosi melalui media cetak seperti poster, billboard dan baliho. Menurut Adisaputro (2010) pemasaran berhubungan dengan mengidentifikasi dan memenuhi kebutuhan manusia. Sedangkan menurut Griffin, Ricky \& J.Ebert (2007) promosi merupakan setiap teknik yang dirancang untuk menjual produk dan ada dua nilai umum yang didapatkan dari setiap kegiatan Promosi: a) Mengkomunikasikan informasi tentang produsen dan produknya bagi pembeli pontesial; dan b) Menciptakan pertukaran yang lebih memuaskan, mencoba membuat produk yang lebih menarik, sehingga baik pembeli maupun penjual mendapatkan lebih banyak dari 
pertukaran (produk yang lebih menarik dan lebih banyak unit terjual atau harga lebih tinggi dan sebaliknya).

Dharmmesta (2007) berpendapat bahwa promosi didefinisikan sebagai arus informasi atau persuasi satu arah yang dibuat untuk mengarahkan seseorang ataupun organisasi kepada tindakan menciptakan pertukaran dalam pemasaran. Sedangkan dalam Kotler \& Keller (2008) dijelaskan bahwa promosi penjualan menjadi bahan inti dalam kampanye pemasaran, terdiri dari koleksi alat insentif, sebagian besar jangka pendek yang dirancang untuk menstimulasi pembelian yang lebih cepat atau lebih besar atas produk atau jasa tertentu oleh konsumen atau perdagangan.

Berdasarkan uraian pengertian promosi diatas maka promosi dapat diartikan sebagai kegiatan yang dilakukan oleh pemasar dengan memberikan informasi tentang suatu produk yang dihasilkan oleh perusahaan untuk menarik konsumen potensial dan diharapkan konsumen dapat melakukan pembelian produk.

\section{Loyalitas Konsumen}

Loyalitas Pelanggan sangat penting artinya bagi perusahaan yang ingin menjaga keberlangsungan hidup maupun keberhasilan usahanya. Olson dalam Musanto (2004) menyatakan bahwa loyalitas pelanggan merupakan dorongan perilaku untuk melakukan pembelian secara berulang-ulang dan membangun kesetiaan pelanggan terhadap suatu produk atau jasa yang dihasilkan oleh badan usaha tersebut membutuhkan waktu yang lama melalui proses pembelian yang berulang-ulang tersebut.

Fourmell dalam Mouren (2004) loyalitas merupakan fungsi dari kepuasan pelanggan, rintangan pengalihan, dan keluhan pelanggan. Pelanggan yang puas akan dapat melakukan pembelian ulang pada waktu yang akan datang dan memberitahukan kepada orang lain apa yang dirasakan.

Beberapa pendapat diatas dapat disimpulkan bahwa loyalitas pelanggan dapat didefinisikan perilaku membeli pelanggan yang loyal dengan melakukan pembelian berulang produk atau jasa secara teratur dan mereferensikan kepada orang lain. Jika pelanggan telah terpuaskan maka akan menjadi pelanggan yang loyal. Griffin (2005) Langkah pertama dalam membangun sistem loyalitas klien adalah berusaha mengenal termologi dan variabel yang menentukan serta mendorong loyalitas. Faktor-faktor tersebut adalah: Basis klien merupakan seluruh jumlah pelanggan dan klien yang aktif, yaitu: a) Tingkat retensi pelanggan baru; b) Tingkat retensi klien; c) Pangsa pelanggan persentase jumlah pembelian pelanggan atas kategori produk dan jasa tertentu yang dibelanjakan ke perusahaan; d) Jumlah rata-rata pelanggan baru per bulan; e) Frekuensi pembelian; f) Jumlah pembelian rata-rata; dan g) Tingkat peralihan.

\section{METODE}

Jenis penelitian ini menggunakan jenis penelitian asosiatif. Sumber data yang digunakan yaitu sumber data primer, data primer merupakan data yang didapatkan langsung dari responden dengan membagikan kuesioner yang berkaitan dengan penelitian ini (pengguna kantong plastik merek Tomat di wilayah Tangerang Kota). Penelitian ini berhubungan dengan sebab akibat (kausal) karena tujuannya untuk mengetahui pengaruh variabel independen dengan variabel intervening terhadap variabel dependent (Sugiyono, 2009). Dalam penelitian 
ini variabel dependen adalah loyalitas (Y), variabel independen adalah citra merek (X1) dan promosi (X2), serta variabel intervening adalah kepuasan konsumen (Z).

Jenis data yang digunakan dalam penelitian ini berupa data kualitatif yang dikuantitatifkan dengan menggunakan Skala Likert. Sedangkan sumber data yang digunakan adalah data primer. Data Primer merupakan data yang diperoleh langsung dari responden yang dilakukan melalui kuesioner atau wawancara. Responden dala penelitian ini diambil sejumlah 100 orang responden. Teknik pengambilan sampel yang digunakan dalam penelitian ini adalah dengan menggunakan teknik non-probability sampling jenis purposive sampling. Uji data dalam penelitian ini terdiri dari uji validitas, uji reliabilitas dan uji analisis jalur.

\section{HASIL DAN PEMBAHASAN}

\section{Uji Validitas}

Pengujian ini dilakukan untuk menguji kesahihan setiap item pernyataan dengan mengkorelasikan skor dari setiap item dengan skor variabel (hasil penjumlahan setiap skor item pernyataan). Teknik korelasi dalam penelitian ini adalah Pearson Product Moment dengan menggunakan tingkat kepercayaan $95 \%$ dimana $\mathrm{df}=\mathrm{n}-2$. Nilai $\mathrm{n}=100$, sehingga nilai $\mathrm{df}=98$ dengan sig 5\%. Dengan begitu, diperoleh nilai $\mathrm{r}_{\text {tabel }}=0,1966$.

Dasar pengambilan keputusan pada uji validitas ini adalah jika koefisien korelasi > 0,1966, maka item dinyatakan valid, Jika koefisien korelasi < 0,1966, maka item dinyatakan tidak valid. Adapun hasil uji validitas kuesioner untuk variabel yang diteliti disajikan pada tabel berikut:

Tabel 1. Hasil Uji Validitas

\begin{tabular}{|c|c|c|c|c|}
\hline Variabel & No. Instrumen & R hitung & R tabel & Kesimpulan \\
\hline \multirow{4}{*}{$\begin{array}{c}\text { Citra Merek } \\
\text { (X1) }\end{array}$} & $\mathrm{X} 1.1$ & 0.781 & 0.196 & Valid \\
\cline { 2 - 5 } & $\mathrm{X} 1.2$ & 0.725 & 0.196 & Valid \\
\cline { 2 - 5 } & $\mathrm{X} 1.3$ & 0.778 & 0.196 & Valid \\
\cline { 2 - 5 } & $\mathrm{X} 1.4$ & 0.774 & 0.196 & Valid \\
\cline { 2 - 5 } & $\mathrm{X} 1.5$ & 0.777 & 0.196 & Valid \\
\cline { 2 - 5 } & $\mathrm{X} 1.6$ & 0.770 & 0.196 & Valid \\
\cline { 2 - 5 } & $\mathrm{X} 1.7$ & 0.748 & 0.196 & Valid \\
\hline \multirow{5}{*}{ Promosi (X2) } & $\mathrm{X} 1.9$ & 0.699 & 0.196 & Valid \\
\cline { 2 - 5 } & $\mathrm{X} 2.1$ & 0.580 & 0.196 & Valid \\
\cline { 2 - 5 } & $\mathrm{X} 2.2$ & 0.840 & 0.196 & Valid \\
\cline { 2 - 5 } & $\mathrm{X} 2.3$ & 0.822 & 0.196 & Valid \\
\cline { 2 - 5 } & $\mathrm{X} 2.4$ & 0.854 & 0.196 & Valid \\
\cline { 2 - 5 } & $\mathrm{X} 2.5$ & 0.825 & 0.196 & Valid \\
\cline { 2 - 5 } & $\mathrm{X} 2.6$ & 0.806 & 0.196 & Valid \\
\cline { 2 - 5 } & $\mathrm{X} 2.7$ & 0.727 & 0.196 & Valid \\
\hline & $\mathrm{X} 2.8$ & 0.711 & 0.196 & Valid \\
\cline { 2 - 5 } & $\mathrm{Z} 1$ & 0.769 & 0.196 & Valid \\
\cline { 2 - 5 } & $\mathrm{Z} 2$ & 0.820 & 0.196 & Valid \\
\cline { 2 - 5 } & $\mathrm{Z} 3$ & 0.882 & 0.196 & Valid \\
\hline
\end{tabular}


ARTIKEL

\begin{tabular}{|c|c|c|c|c|}
\hline Variabel & No. Instrumen & R hitung & R tabel & Kesimpulan \\
\hline & Z4 & 0.867 & 0.196 & Valid \\
\hline \multirow{4}{*}{ Loyalitas (Y) } & Y1 & 0.632 & 0.196 & Valid \\
\cline { 2 - 5 } & Y2 & 0.594 & 0.196 & Valid \\
\cline { 2 - 5 } & Y3 & 0.514 & 0.196 & Valid \\
\cline { 2 - 5 } & Y4 & 0.558 & 0.196 & Valid \\
\cline { 2 - 5 } & Y5 & 0.705 & 0.196 & Valid \\
\cline { 2 - 5 } & Y6 & 0.705 & 0.196 & Valid \\
\hline
\end{tabular}

\section{Sumber: Data Diolah}

Berdasarkan tabel diatas, terlihat bahwa seluruh item pernyataan memiliki koefisien validitas yang lebih besar dari nilai $r_{\text {tabel. }}$ Sehingga dapat disimpulkan bahwa semua item tersebut valid dan dapat dikatakan layak digunakan sebagai alat ukur untuk proses analisis selanjutnya.

\section{Uji Reliabilitas}

Pengukuran reliabilitas pada penelitian ini dibuktikan dengan menguji instrument sekali saja, kemudian dilakukan analisis dengan menggunakan metode Alpha-Cronbach. Kuesioner dikatakan andal apabila koefisien realibilitas bernilai positif dan >0,6. Adapun hasil dari uji reliabilitas adalah sebagai berikut:

Tabel 2. Hasil Uji Reliabilitas

\begin{tabular}{|c|c|c|}
\hline Variabel & Alpha Cronbach & Kesimpulan \\
\hline Citra Merek $\left(\mathrm{X}_{1}\right)$ & 0.896 & Reliabel \\
\hline Promosi $\left(\mathrm{X}_{2}\right)$ & 0.921 & Reliabel \\
\hline Kepuasan $(\mathrm{Z})$ & 0.849 & Reliabel \\
\hline Loyalitas $(\mathrm{Y})$ & 0.677 & Reliabel \\
\hline
\end{tabular}

Sumber: Data Diolah

Berdasarkan hasil pengujian reliabilitas di atas diketahui bahwa hasil nilai dari setiap variabel menunjukan nilai Alpha-Cronbach cukup besar dari 0,6 sehingga variabel dapat dikatakan reliabel dan butir-butir pernyataan pada kuesioner mampu untuk mengukur variabelnya.

\section{Uji Hipotesis Parsial (Uji t)}

Tabel 3. Hasil Estimasii Uji Hipotesis Parsial Coefficients $^{\mathrm{a}}$

\begin{tabular}{|ll|c|c|c|c|c|}
\hline \multirow{2}{*}{ Model } & \multicolumn{3}{|c|}{ Coefficients $^{\text {Unstandardized Coefficients }}$} & $\begin{array}{c}\text { Standardized } \\
\text { Coefficients }\end{array}$ & & \\
\cline { 3 - 5 } & & $\mathrm{B}$ & Std. Error & Beta & $\mathrm{t}$ & Sig. \\
\hline & (Constant) & 7.210 & 1.248 & & 5.776 & .000 \\
& Citra Merek & .153 & .054 & .278 & 2.808 & .006 \\
& Promosi & .138 & .046 & .245 & 3.005 & .003 \\
& Kepuasan & .463 & .124 & .421 & 3.727 & .000 \\
\hline
\end{tabular}

a. Dependent Variable: Loyalitas

Berdasarkan output di atas, diperoleh nilai t hitung untuk Citra Merek $\left(\mathrm{X}_{1}\right)$ sebesar 2.808, Promosi $\left(\mathrm{X}_{2}\right)$ sebesar 3.005, dan untuk variabel Kepuasan $(\mathrm{Z})$ sebesar 3.727. Nilai ini kemudian akan dibandingkan dengan nilai t tabel sebesar 1.985. maka dapat diambil kesimpulan bahwa Citra Merek $\left(\mathrm{X}_{1}\right)$ secara parsial berpengaruh signifikan terhadap Loyalitas 
(Y). Hal tersebut dapat dikatakan bahwa citra merek yang meliputi merek mudah diucapkan, desain dan warna yang menarik, kantong plastik tidak mudah bocor, kantong plastik merek tomat aman digunakan untuk makanan dan minuman serta tingkat kepercayaan konsumen yang tinggi ketika membandingkan merek lain.

Varibel promosi hasil penelitian yang diperoleh bahwa t hitung $3.005>\mathrm{t}$ tabel 1.985 sehingga $\mathrm{H}_{0}$ ditolak dan $\mathrm{H}_{\mathrm{a}}$ diterima. Berdasarkan hal tersebut dapat diambil kesimpulan bahwa Promosi $\left(\mathrm{X}_{2}\right)$ berpengaruh signifikan terhadap Loyalitas $(\mathrm{Y})$. Hal tersebut dapat dikatakan bawah promosi yang meliputi indokator periklanan yaitu, pesan iklan yang disampaikan dengan lengkap kepada konsumen, dan pesan yang disampaikan menarik kemudian indikator hubungan dengan masyarakat yaitu, konsumen memiliki perasaan senang karna kantong plastik merek tomat selalu melakukan promosi dengan grebek pasar, promosi yang dilakukan selalu inovasi, dan ketika melakukan stand bazar selalu memberikan perhatian atau membuat konsumen tertarik untuk membeli sehingga dapat disimpulan promosi memiliki pengaruh signifikan terhadap loyalitas konsumen.

Varabel Kepuasan diketahui bahwa t hitung $3.727>\mathrm{t}$ tabel 1.985 sehingga $\mathrm{H}_{0}$ ditolak dan $\mathrm{H}_{\mathrm{a}}$ diterima. Hal tersebut dapat dikatakan karena indikator yang meliputi merek tomat memiliki variasi ukuran yang lengkap dibandingkan merek lain, merek tomat sangat membantu usaha konsumen, merek tomat tidak mudah bocor, merek tomat mudah ditemukan di tokotoko. Sehingga disimpulkan bahwa Kepuasan (Z) berpengaruh signifikan terhadap Loyalitas (Y).

Maka dapat dijelaskan dekomposisi hipotesis pengaruh langsung dan pengaruh tidak langsung yang terjadi antar variabel sebagai berikut:

$1 \mathrm{H}_{0}: \mathrm{P}_{\mathrm{ZX} 1}=0$; Citra Merek $\left(\mathrm{X}_{1}\right)$ tidak berpengaruh signifikan terhadap Loyalitas $(\mathrm{Y})$ melalui Kepuasan $(\mathrm{Z})$.

$\mathrm{H}_{1}: \mathrm{P}_{\mathrm{ZX} 1} \neq 0$; Citra Merek $\left(\mathrm{X}_{1}\right)$ berpengaruh signifikan terhadap Loyalitas (Y) melalui Kepuasan (Z).

$2 \mathrm{H}_{0}: \mathrm{P}_{\mathrm{ZX} 2}=0$; Promosi $\left(\mathrm{X}_{2}\right)$ tidak berpengaruh signifikan terhadap Loyalitas $(\mathrm{Y})$ melalui Kepuasan $(\mathrm{Z})$

$\mathrm{H}_{1}: \mathrm{P}_{\mathrm{ZX} 2} \neq 0$; Promosi $\left(\mathrm{X}_{2}\right)$ berpengaruh signifikan terhadap Loyalitas (Y) melalui Kepuasan $(\mathrm{Z})$

\section{Pengaruh Citra Merek terhadap Kepuasan Konsumen pada Produk Kantong Plastik}

Hasil penelitian membuktikan bahwa terdapat pengaruh positif dan signifikan antara citra merek terhadap kepuasan konsumen. Artinya jika citra merek yang dimiliki sudah baik dan sesuai dengan apa yang diinginkan konsumen maka akan timbul rasa kepuasan.

Dapat dilihat dari karakteristik responden yang jenis usahanya dominan pada makanan sebanyak 81 orang, artinya bahwa pengguna produk kantong plastik dominan dimanfaatkan oleh pedagang makanan. Jika dilihat dari hasil skala pengukuran nilai indeks, berdasarkan varibel citra merek yang meliputi : Kantong Plastik merek Tomat memiliki design dan warna yang menarik, Kantong Plastik merek Tomat mudah diucapkan, Merek Kantong Plastik Tomat tidak mudah bocor (kualitas produk terjamin), Kantong Plastik merek Tomat aman digunakan untuk Makanan dan Minuman, Saya lebih tertarik menggunakan Kantong Plastik merek Tomat dibandingkan merek lain, Saya tidak yakin bahwa merek lain lebih baik dari merek Tomat, 
Saya merasa senang dan terbantu dengan menggunakan Kantong Plastik merek Tomat, Kantong Plastik merek Tomat sudah dikenal banyak orang, dan Kantong Plastik merek Tomat mudah di ingat, berdasarkan index tertinggi terdapat pada indikator Kantong Plastik merek Tomat sudah dikenal banyak orang. Sedangkan indeks terendah terdapat pada indikator Kantong Plastik merek Tomat aman digunakan untuk Makanan dan Minuman. Hal ini membuktikan suatu produk kantong plastik dengan menciptakan brand semakin dikenal banyak orang dapat meningkatkan rasa kepuasan konsumen.

Penelitian ini sejalan oleh teori Fitriani (2019) yang berjudul "Pengaruh Kualitas Produk dan Citra Merek Terhadap Kepuasan Konsumen dalam membentuk Loyalitas" dinyatakan bahwa citra merek berpengaruh secara langsung terhadap kepuasan para konsumen. Diartikan semakin tinggi brand image maka akan mampu meningkatkan kepuasan konsumen.

\section{Pengaruh Promosi terhadap Kepuasan Konsumen pada Produk Kantong Plastik}

Hasil penelitian ini menunjukan terdapat pengaruh antara Promosi terhadap Kepuasan Konsumen di Produk Kantong Plastik merek Tomat. Hasil penelitian ini didapatkan dari responden terbanyak dengan intensitas pembelian seminggu dua kali sebanyak 88 orang. Artinya apabila suatu perusahaan selalu melakukan Promosi dan membangun sebuah hubungan dengan masyarakat dan selalu memberikan informasi produk yang dihasilkan seperti melalui iklan maka akan meningkatkan kepuasan bagi konsumen. Jika dilihat dari hasil skala pengukuran nilai indeks, berdasarkan varibel promosi yang meliputi : Apakah anda setuju, pesan Iklan mengenai Kantong Plastik Tomat disampaikan dengan lengkap, Apakah anda setuju, pesan yang disampaikan Kantong Plastik Tomat dalam iklan dan spanduk jelas, Apakah anda setuju, iklan Kantong Plastik merek Tomat menarik, Apakah anda setuju, Kantong Plastik yang beriklan di televisi hanya merek Tomat, Apakah anda setuju, Kantong Plastik merek Tomat melakukan promosi dengan grebek pasar, Event yang dibuat untuk mempromosikan, dan Kantong Plastik Tomat selalu berinovasi dari waktu ke waktu. berdasarkan index tertinggi terdapat pada indikator pesan yang disampaikan Kantong Plastik Tomat dalam iklan dan spanduk jelas dan pesan Iklan mengenai Kantong Plastik Tomat disampaikan dengan lengkap.

Penelitian ini sejalan dengan penelitian yang dilakukan oleh Puteri Andira (2018) yang berjudul "Pengaruh Promosi, Pelayanan, dan Lokasi terhadap Kepuasan Pelanggan pada Khalifah Hotel Syariah Palembang” dinyatakan bahwa promosi merupakan faktor penting dala usaha pemasaran, suatu usaha untuk menarik pelanggan, adanya peningkatan promosi, pelayanan dan lokasi akan berpengaruh terhadap kepuasan pelanggan secara signifikan.

\section{Pengaruh Citra Merek terhadap Loyalitas Konsumen pada Produk Kantong Plastik Merek Tomat}

Hasil penelitian membuktikan bahwa terdapat pengaruh positif dan signifikan variabel citra merek terhadap loyalitas konsumen. Artinya jika citra merek yang dimiliki sudah baik dan sesuai dengan apa yang diinginkan konsumen maka dapat mempengaruhi langsung terhadap loyalitas konsumen. Jika dilihat dari hasil skala pengukuran nilai indeks, berdasarkan varibel citra merek yang meliputi : Kantong Plastik merek Tomat memiliki design dan warna yang menarik, Kantong Plastik merek Tomat mudah diucapkan, Merek Kantong Plastik Tomat tidak mudah bocor (kualitas produk terjamin), Kantong Plastik merek Tomat aman digunakan untuk Makanan dan Minuman, Saya lebih tertarik menggunakan Kantong Plastik merek Tomat 
dibandingkan merek lain, Saya tidak yakin bahwa merek lain lebih baik dari merek Tomat, Saya merasa senang dan terbantu dengan menggunakan Kantong Plastik merek Tomat, Kantong Plastik merek Tomat sudah dikenal banyak orang, dan Kantong Plastik merek Tomat mudah di ingat, berdasarkan index tertinggi terdapat pada indikator Kantong Plastik merek Tomat sudah dikenal banyak orang. Sedangkan indeks terendah terdapat pada indikator Kantong Plastik merek Tomat aman digunakan untuk Makanan dan Minuman. Hal ini membuktikan suatu produk kantong plastik dengan menciptakan brand semakin dikenal banyak orang dapat meningkatkan rasa kepuasan konsumen.

Penelitian ini didukung oleh teori A. M. Ananda (2018) yang berjudul "Pengaruh Harga, Citra Merek dan Promosi terhadap Loyalitas Konsumen Kopi Kapal Api” dinyatakan bahwa semakin tinggi citra merek yang dimiliki perusahaan maka semakin tinggi terciptanya loyalitas konsumen saat menggunakan suatu produk citra merek berpengaruh positif terhadap loyalitas konsumen.

\section{Pengaruh Promosi terhadap Loyalitas Konsumen pada Produk Kantong Plastik Merek Tomat}

Hasil penelitian ini menunjukan terdapat pengaruh Promosi terhadap Kepuasan Konsumen di Produk Kantong Plastik merek Tomat. Hasil penelitian ini jika dilihat dari hasil skala pengukuran nilai indeks, berdasarkan varibel promosi yang meliputi : Apakah anda setuju, pesan Iklan mengenai Kantong Plastik Tomat disampaikan dengan lengkap, Apakah anda setuju, pesan yang disampaikan Kantong Plastik Tomat dalam iklan dan spanduk jelas, Apakah anda setuju, iklan Kantong Plastik merek Tomat menarik, Apakah anda setuju, Kantong Plastik yang beriklan di televisi hanya merek Tomat, Apakah anda setuju, Kantong Plastik merek Tomat melakukan promosi dengan grebek pasar, Event yang dibuat untuk mempromosikan, dan Kantong Plastik Tomat selalu berinovasi dari waktu ke waktu. berdasarkan index tertinggi terdapat pada indikator pesan yang disampaikan Kantong Plastik Tomat dalam iklan dan spanduk jelas dan pesan Iklan mengenai Kantong Plastik Tomat disampaikan dengan lengkap. Dapat diartikan bahwa semakin sering perusahaan melakukan periklanan seperti promosi di televisi, youtube, dan tiktok maka akan membuat konsumen merasa senang dan kalua dilakukan terus-menerus mampu memberikan nilai positif kepada Loyalitas Konsumen.

Penelitian ini sejalan dengan penelitian yang dilakukan A. M. Ananda (2018) bahwa semakin sering promosi yang diberikan oleh perusahaan kepada konsumen maka keinginan konsumen untuk mencoba suatu produk akan menjadi semakin tinggi sehingga suatu peluang loyalitas konsumen akan tercipta.

\section{Pengaruh Kepuasan terhadap Loyalitas Konsumen pada Produk Kantong Plastik Merek Tomat}

Hasil penelitian ini membuktikan bahwa kepuasan konsumen dapat berpengaruh positif terhadap loyalitas konsumen yang artinya konsumen yang merasa puas dari pengalaman setelah menggunakan produk yang ditawarkan oleh perusahaan akan melakukan pembelian kembali pada suatu barang yang ditawarkan oleh perusahaan tersebut. jika dilihat dari hasil skala pengukuran nilai indeks, berdasarkan varibel kepuasan yang meliputi: Kantong Plastik merek Tomat memiliki variasi ukuran yang lengkap dibandingkan merek lain, Kantong Plastik merek 
Tomat sangat membantu usaha saya, Kantong Plastik merek Tomat berkualitas (tidak mudah bocor), Kantong Plastik merek dan Tomat mudah ditemukan di toko-toko. berdasarkan index tertinggi terdapat pada dua indikator yaitu: Kantong Plastik merek Tomat berkualitas (tidak mudah bocor) dan Kantong Plastik merek Tomat mudah ditemukan di toko-toko.

Penelitian ini sejalan dengan penelitian yang dilakukan oleh Fitriani (2019) yang berjudul "Pengaruh Kualitas Produk dan Citra Merek Terhadap Kepuasan Konsumen dalam membentuk Loyalitas" bahwa semakin tinggi kepuasan konsumen maka akan mampu meningkatkan loyalitas pelanggan.

\section{Pengaruh Citra Merek terhadap Loyalitas Konsumen melalui Kepuasan Produk Kantong Plastik merek Tomat}

Berdasarkan hasil penelitian kepuasan adalah variabel yang mampu mempengaruhi citra merek terhadap loyalitas konsumen. Artinya citra merek dapat memberikan pengaruh kepada loyalitas konsumen, baik secara langsung ataupun melalui mediasi kepuasan. Dari hasil pengujian menyatakan besarnya nilai hitung $\mathrm{Z}$ adalah 3.357 dimana hasil tersebut lebih besar dari nilai $\mathrm{Z}$ sobel 1.96. Hal ini dapat diartikan bahwa kepuasan dapat berkontribusi untuk meningkatkan pengaruh loyalitas konsumen. Citra merek yang dikenal oleh banyak orang dengan kualitas produk yang terjamin dapat memberikan kepuasan kemudian kepuasan tersebut memberikan pengaruh besar kepada loyalitas konsumen, oleh sebab itu ketika citra merek dapat memberikan kepuasan maka kepuasan akan langsung mempengaruhi loyalitas konsumen. Artinya kepuasan yang diberikan dari sebuah citra merek yang baik dapat dimediasi menjadi konsumen yang loyal melalui kepuasan.

Hasil penelitian ini sejalan dengan penelitian yang sudah dilakukan oleh Fitriani (2019) dinyatakan Citra Merek berpengaruh terhadap loyalitas konsumen baju H\&M dengan kepuasan konsumen sebagai variabel intervening.

\section{Pengaruh Promosi terhadap Loyalitas Konsumen melalui Kepuasan pada Produk Kantong Plastik Merek Tomat}

Hasil penelitian ini membuktikan promosi dapat memberikan pengaruh kepada loyalitas konsumen yang dimediasi oleh kepuasan. kepuasan adalah variabel yang mampu mempengaruhi variabel promosi untuk meningkatkan loyalitas konsumen. Artinya promosi dapat memberikan pengaruh kepada loyalitas konsumen, baik secara langsung ataupun melalui mediasi kepuasan. Dari hasil pengujian menyatakan besarnya nilai hitung $\mathrm{Z}$ adalah 3.303 dimana hasil tersebut lebih besar dari nilai $Z$ sobel 1.96. Hal ini dapat diartikan bahwa kepuasan yang diterima oleh konsumen dari promosi tentang pesan yang disampaikan untuk memberikan informasi produk kepada konsumen dapat meningkatkan konsumen semakin loyal. oleh sebab itu ketika promosi dapat memberikan kepuasan maka kepuasan akan langsung mempengaruhi kepada loyalitas konsumen. Artinya kepuasan yang diberikan dari promosi yang benar akan dapat diterima dan langsung dimediasi oleh kepuasan, sehingga dapat disimpulkan bahwa variabel kepuasan dapat memediasi promosi terhadap loyalitas konsumen.

Hasil penelitian ini sejalan dengan penelitian yang sudah dilakukan oleh Stefanus Maximus Lamere (2017) dengan judul penelitian "Pengaruh Harga, Lokasi, Produk, dan Promosi terhadap Loyalitas Konsumen dengan Kepuasan sebagai variabel Mediasi” 
dinyatakan bahwa Kepuasan konsumen tidak memediasi pengaruh promosi terhadap Loyalitas konsumen.

\section{E. KESIMPULAN}

Berdasarkan analisis data hasil penelitian, dapat disimpulkan bahwa: 1) Citra Merek (X1) dan Promosi (X2) berpengaruh terhadap kepuasan (Z); 2) Citra Merek (X1) dan Promosi (X2) berpengaruh terhadap Loyalitas (Y); 3) Kepuasan (Z) berpengaruh terhadap Loyalitas (Y); dan 4) Citra Merek ( $\left.\mathrm{X}_{1}\right)$ dan Promosi (X2) memiliki pengaruh terhadap loyalitas konsumen melalui kepuasan konsumen Produk Kantong Plastik merek Tomat.

\section{DAFTAR PUSTAKA}

Adisaputro, G. (2000). Manajemen Pemasaran (Analisis untuk Perancangan Strategi Pemasaran). Yogyakarta: Sekolah Tinggi Ilmu Manajemen (YKPN).

Adisaputro, G. (2010). Manajemen Pemasaran: Analisis untuk Perancangan Strategi Pemasaran. Yogyakarta: UPP STIM YKPN.

Ananda, A. (2011). Manajemen Ekuitas Merek: Memanfaatkan Nilai Dari Suatu Merek. Jakarta: Spektrum Mitra Utama.

Ananda, A. M. (2018). Pengaruh Harga, Citra Merek dan Promosi Terhadap Loyalitas Konsumen Kopi Kapal Api Pada Masyarakat di Kota Palembang. Raden Fatah Palembang.

Andira, P. (2018). Pengaruh Promosi, Pelayanan Dan Lokasi Terhadap Kepuasan Pelanggan Pada Khalifah Hotel Syariah Palembang. Universitas Islam Negeri Raden Fatah.

Arianto, N. (2019). Pengaruh Promosi Dan Kualitas Pelayanan Terhadap Kepuasan Serta Berdampak Terhadap Loyalitas Pelanggan. KREATIF: Jurnal Ilmiah Prodi Manajemen Universitas Pamulang, 7(1), 44.

Award, T. B. (2020). Top Brand Index Kantong Plastik 2020. Retrieved from https://www.topbrand-award.com/en/top-brand-index-\%09int/?tbi_year=2020.

Bilson, S. (2011). Memenangkan Pasar dengan Pemasaran Efektif dan Profitabel. Jakarta: PT. Gramedia Pustaka Utama.

David, H. (2018). Pengaruh Citra Merek Terhadap Loyalitas Konsumen. Jurnal Ilmu Manajemen.

Dewi, N. K., Andri, G., \& Yonaldi, S. (2012). Pengaruh Iklan, Citra Merek, dan Kepuasan Konsumen terhadap Loyalitas Konsumen Dalam Menggunakan Vaseline Hand And Body Lotion di Kota Padang (Studi Kasus di PT. Unilever Cabang Padang). Jurnal Manajemen dan Kewirausahaan, 3(2).

Dharmmesta, B. S. (2007). Pengantar Bisnis Modern (Edisi 3). Yogyakarta: Liberty.

Engel. (2002). Perilaku Konsumen. Alih Bahasa Drs F.X. Budiyanto. Jakarta: Binarupa Aksara. Fang, G., Susanto, R. D., Wirasantosa, S., Qiao, F., Supangat, A., Fan, B., ... Li, S. (2010). Volume, heat, and freshwater transports from the South China Sea to Indonesian seas in the boreal winter of 2007-2008. Journal of Geophysical Research: Oceans, 115(12), $1-11$.

Fitriani. (2019). Pengaruh Kualitas Produk dan Citra Merek Terhadap Kepuasan Konsumen dalam membentuk Loyalitas (Universitas Sanata Dharma). Universitas Sanata Dharma.

Ghozali, I. (2011). Aplikasi Analisis Multivariate Dengan Program SPSS. Semarang: Badan Penerbit Universitas Diponegoro.

Ghozali, I. (2015). Partial Least Squares Konsep, Teknik dan Aplikasi Menggunakan Program SmartPLS 3.0. Semarang: Universitas Diponegoro. 
Griffin, J. (2005). Customer Loyalty: Menumbuhkan \& Mempertahankan Kesetiaan Pelanggan. Jakarta: Erlangga.

Griffin, R. W., \& J.Ebert, R. (2007). Bisnis. Jakarta: Erlangga.

Hendrayani, D. (2013). Pengaruh Komitmen dan Job Insecurity Terhadap Intensi Turnover Pada Operator Garuda Call Center. Jurnal MIX, 3(1), 1689-1699.

Javadein, S. R. S., Khanlari, A., \& Estiri, M. (2008). Customer loyalty in the sport services industry: the role of service quality, customer satisfaction, commitment and trust. International Journal of Human Sciences, 5, 1-19.

KataData. (2020). Lima Alasan UMKM Masih Menggunakan Kantong Plastik.

Kotler, P., \& Amstrong, G. (2011). Principle Of Marketing. New Jersey: Prentice Hall.

Kotler, P., \& Armstrong, G. (2008). Prinsip-prinsip Pemasaran. Jakarta: Erlangga.

Kotler, P., \& Keller, K. L. (2006). Marketing Management. Pearson Education.

Kotler, P., \& Keller, K. L. (2008). Manajemen Pemasaran. Jakarta: Erlangga.

Lamere, S. M. (2017). Pengaruh harga, lokasi, produk, dan promosi terhadap loyalitas konsumen dengan kepuasan konsumen sebagai variabel mediasi. Universitas Sanata Dharma.

Lupiyoadi. (2001). Manajemen Pemasaran Jasa Teori dan Praktek. Jakarta: Salemba Empat.

Mouren, M. (2004). Studi mengenai loyalitas pelanggan pada divisi asuransi kumpulan AJP bumi Putra. Jurnal Sains Pemasaran Indonesia, 3(3), 297.

Muhammad, R. I. (2018). Pengaruh Promosi Terhadap Loyalitas Konsumen.

Musanto, T. (2004). Faktor-Faktor Kepuasan Pelanggan dan Loyalitas Pelanggan: Studi Kasus pada CV. Sarana Media Advertising Surabaya. Jurnal Manajemen Dan Kewirausahaan, 6(2), 123-136.

Oliver, R. L. (1997). Satisfaction A Behavioral Perspective On The Consumer. Singapore: McGraw-Hill Education.

Patterson, P. G., \& Spreng, R. A. (1997). Modelling the relationship between perceived value, satisfaction and repurchase intentions in a business-to- business, services context: an empirical examination. International Journal of Service Industry Management, 8(5), 414-434.

Revita Ela, M. L. D., Frimayasa, A., \& Kurniawan, A. (2018). Pengaruh Kualitas Produk Terhadap Keputusan Pembelian Smartphone Merek Samsung. Managerial - Jurnal Penelitian Ilmu Manajemen, 1(1), 10-10.

Sangadji, \& Sopiah. (2013). Perilaku Konsumen: Pendekatan Praktis Disertai Himpunan Jurnal Penelitian. Yogyakarta: Andi.

Sekaran, U. (2003). Research Methods For Business: A Skill Building Aproach. New YorkUSA: John Wiley and Sons, Inc.

Shimp, T., \& Craig, A. (2013). Advertising, Promotion, and other aspects of Integrated Marketing Communications. Cengage Learning, 327.

Sugiyono. (2006). Metode Penelitian Kuantitatif, Kualitatif dan $R \& D$. Bandung: Alfabeta.

Sugiyono. (2009). Metode Penelitian Kuantitatif, Kualitatif dan R\&D. Bandung: Alfabeta.

Sugiyono. (2010). Metode Penelitian Pendidikan Pendekatan Kuantitatif, kualitatif, dan R\&D. Bandung: Alfabeta.

Sugiyono. (2012). Metode Penelitian Kuantitatif Kualitatif dan $R \& B$. Bandung: Alfabeta.

Sugiyono. (2013). Metode Penelitian Bisnis. Bandung: Alfabeta.

Sugiyono. (2014). Metode Penelitian Pendidikan Pendekatan Kuantitatif, Kualitatif, dan R\&D. Bandung: Alfabeta.

Sugiyono. (2016). Metode Penelitian Kuantitatif, Kualitatif dan R\&D. Bandung: Alfabeta. Sugiyono. (2017). Metode Penelitian Kuantitatif, JKualitatif dan R\&D. Bandung: Alfabeta. Sugiyono, \& Susanto, A. (2015). Cara Mudah Belajar SPSS \& Lisrel. Bandung: Alfabeta. 
Suparman, \& Arifin, R. (2017). Pengaruh Citra Merek, Citra Perusahaan Dan Kualitas Produk Terhadap Proses Keputusan Pembelian Smartphone Merek Samsung (Studi Pada Mahasiswa Fakultas Ekonomi Universitas Islam Malang). Jurnal Riset Manajemen, $124-135$.

Tjiptono, F. (2002). Manajemen Jasa (Edisi Mare). Yogyakarta: Andi Yogyakarta Majalah Info Bisnis.

Tjiptono, F. (2011). Strategi Pemasaran (Edisi 3). Yogyakarta: ANDI.

Tse, \& Wilton. (1998). Kepuasan Pelanggan (Edisi keti). Klaten: Indeks Kelompok Gramedia.

Umar, H. (2005). Manajemen Riset dan Perilaku Konsumen. Jakarta: Gramedia Pustaka Utama.

Wibawa, P. T., \& Farida, N. (2018). Pengaruh Promosi Terhadap Loyalitas Konsumen.

Yusuf., A. M. (2014). Metodologi Penelitian Kuantitatif, Kualitatif \& Penelitian Gabungan. Jakarta: Prenadamedia Group.

Yusuf., A. M. (2017). Metode Penelitian: Kuantitatif, Kualitatif, dan Penelitian Gabungan. Jakarta: Kencana. 